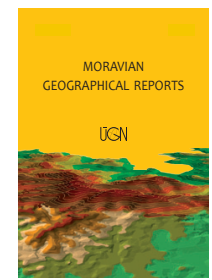

MORAVIAN GEOGRAPHICAL REPORTS

\title{
The spatial distribution of gambling and its economic benefits to municipalities in the Czech Republic
}

\author{
David FIEDOR $^{\text {a * }}$, Zdeněk SZCZYRBA ${ }^{\mathrm{b}}$, Miloslav ŠERÝ ${ }^{\mathrm{b}}$, Irena SMOLOVÁ ${ }^{\mathrm{b}}$, Václav TOUŠEK ${ }^{\mathrm{b}}$
}

\begin{abstract}
Gambling is a specific type of economic activity that significantly affects many aspects of society. It is associated mainly with negative impacts on the lives of individuals and their families, but it also has a positive economic impact on the public budgets of states, regions and municipalities. In this article, we focus on a geographic assessment of the development of gambling in the Czech Republic, which is based on a spatial analysis of data on licensed games and data on the revenues of municipalities arising from gambling. It turns out that the occurrence of gambling is strongly influenced by binary centre/periphery dichotomy, with the exception of the Czech-Austrian and Czech-German border areas which are characterised by a high concentration of casinos resulting from more rigid regulation of gambling on the other side of the border. In this research, the authors develop an innovative scientific discipline within Czech human geography: The geography of gambling.
\end{abstract}

Keywords: gambling, regulation, municipalities, spatial patterns, economic benefits, Czech Republic

Article history: Received 1 August 2016; Accepted 12 May 2017; Published 30 June 2017

\section{Introduction}

Gambling is analysed in this contribution as it is connected with a specific type of socio-economic activity that has a number of significant impacts on a society and its economy (Williams, Rehm and Stevens, 2011). From this viewpoint, gambling appears to be an important social phenomenon. Its importance is also underlined by the fact that it is an historical phenomenon that has been accentuated during the $20^{\text {th }}$ century (McMillen, 1996).

The Czech Republic has been experiencing gambling since at least the 5 or $6^{\text {th }}$ centuries BCE (Szczyrba et al., 2015, p. 1). According to Mravčík et al. (2014), the gambling landscape of the Czech Republic is highly developed, such that it is one of the European countries with a high availability of gambling. Moreover, international data collected by the Australasian Gaming Council underlines a very strong position for Czech gambling on a global scale (Ziolkowski, 2016).

In spite of these facts, there has been a rather insufficient effort in research on gambling in the Czech Republic. This paper extends the present state of understanding of gambling in the Czech Republic in terms of its geography. Furthermore, the paper attempts to contribute to current theory regarding the geography of gambling, because a principal aim is to assess the spatial patterns of both the diffusion and economic aspects of gambling based on data from the Czech Republic. Specific research questions can be formulated as follows.

First, what is the spatial distribution of Electronic Gaming Machines (hereinafter EGMs) in the Czech Republic? Are there any spatial patterns or is their deployment irregular? Does the binary dichotomy "centre vs. periphery" apply for EGMs? Does the phenomenon of a borderland have any importance?

Second, are there any spatial patterns regarding the revenues from gambling that accrue to the budgets of individual municipalities? Again, the existence of the binary dichotomy "centre vs. periphery" is evaluated. Is the size of the population of settlements important in this context? Considering the fact that the attributes of gambling that are being tackled are not static and evolve over time, we will be interested in their recent dynamics, which, in the case of gambling, are strongly associated with changes in the legislative framework. The most recent significant legislative change affecting gambling in the Czech Republic took place in 2011.

\footnotetext{
${ }^{a}$ Department of Geography, Faculty of Science, Masaryk University, Brno, Czech Republic (*corresponding author: D. Fiedor, e-mail: david.fiedor@upol.cz)

${ }^{\mathrm{b}}$ Department of Geography, Faculty of Science, Palacký University in Olomouc, Czech Republic
} 
Third, attention will be paid to the intensity of the dynamics of the attributes of gambling under evaluation in the period before and after the aforementioned legislative change. Has the level of spatial concentration of gambling increased in recent years? With regard to the year of implementation of the legislative change (see below) and the currency of the data that is needed, we will also investigate changes in the character of the attributes of gambling under evaluation in the period 2010-2014 ${ }^{1}$.

In connection with this research, it is necessary to mention the Amendment to the Lottery Act No. 300/2011 Coll., that changed the system by which gambling companies are taxed, and contributed to an increase in the tax revenues paid to municipalities. At the same time, municipalities were granted competencies to regulate gambling operations in their jurisdictions. Mainly for this reason, the research questions were formulated not only to capture the extent of the above-mentioned attributes of gambling, but also to capture the dynamics of their evolution by comparing the years before and after the Amendment to the Lottery Act, i.e. by comparison of the available data from the years 2010 and 2014.

\section{Theoretical background}

At this point in time, betting and its associated gambling or lotteries have become a rapidly-growing industry. Never in history has gambling had such a great economic potential as that which can be observed in recent decades (Shaffer and Hall, 2001). This is largely due to technological progress in the development of gaming machines, and especially the development of the Internet, which has increased the number of opportunities for gamblers and the overall revenue from gambling (Griffiths, 1999). With the development of gambling, the interest of geographers in research into the spatial context of the spread of this phenomenon has also increased. The gambling landscape in an area is the subject of research not only for purely scientific purposes, but also in terms of institutional assessments of the real social impact that gambling brings (Markham, Doran and Young, 2014). An integral part of the gambling landscape in an area is a higher incidence of crime, as evidenced by some studies (e.g. Wheeler, Round and Wilson, 2011).

For the development of gambling in the world, traditions and customs are important factors. Spatial patterns of the development of gambling are significantly determined by the cultural and social characteristics of the environment (McMillen, 1996; Raento and Schwartz, 2011; Binde, 2013). In countries with a tradition of gambling (e.g. the USA, Australia, Finland), there is also a developed gambling landscape (Raento and Schwartz, 2011; Raento, 2014). In contrast, elsewhere in the world, gambling is not sufficiently rooted in society and therefore lacks the cultural conditions for its development. We can see this in the countries of the former socialist bloc in Central and Eastern Europe, which have a different cultural and historical background in comparison to the rest of Europe. For example, compared to the popular so-called First Republic (1918-1938), gambling was strictly regulated during the socialist era (Szczyrba et al., 2015). Such regulation resulted in some discontinuity in the cultural conditions of gambling, which started to develop again after 1989 in the transition period.
The relationship between the interests of the gambling industry and the public sector, both at the national level and at regional and local levels, can also determine the proliferation of gambling in an area. At various levels of public administration, so-called gambling policies are formulated, by which countries, regions and sometimes even municipalities, make decisions about the form of gambling, the level of its taxation, location, opening hours of gaming equipment, etc. (Fijnaut and Littler, 2007). At the national level, countries apply different approaches to the control and regulation of gambling or define the parameters of the distribution of gambling centres and machines in the area. Different approaches, however, may occur over time even within a particular country. Such events therefore affect the dynamics of the spatial distribution of gambling over time.

Spatially, the gaming landscape is concentrated mainly in cities and large urban agglomerations (Klebanow and Gallaway, 2015), which, among other things, helps to create an infrastructure for urban tourism. Cities are a key factor in the location of gaming landscapes. On the other hand, the casinos and their complexes change the face and the functional structure of cities, often in terms of the transformation of cities in order to increase their attractiveness (McCarthy, 2002). In urban areas, geographical research has uncovered the spatial distribution of gambling establishments using the concept of availability (see Robitaille and Herjean, 2008; Križan, Bilková, Kita and Horňák, 2015; Russnák et al., 2016; Fiedor, 2016), and the concept of accessibility (see Doran and Young, 2010; Young, Markham and Doran, 2009; Young, Markham and Doran, 2012). Marshall (2005) distinguishes several attributes of availability: geographic, temporal and social. Other authors discuss 'geo-temporal availability', to which they also add financial availability (Moore et al., 2011; Thomas et al., 2011). Most empirical studies have confirmed a link between the geographic accessibility of gambling establishments and the prevalence of problem gambling (Pearce et al., 2008; Welte et al., 2009; Welte et al., 2004). For example, Pearce et al. (2008) found in their study that people living within 700 metres of casinos, gambling centres or betting shops, have twice as high a probability of becoming problematic players than residents living at a distance of more than three kilometres away from gambling premises.

The spatial spread of gambling is also significantly connected with socio-economically deprived areas, i.e. regions with a population with lower social status and economic problems (Orford et al., 2010). The reasons for the expansion of gambling in this type of territory have been explained, inter alia, by the lack of leisure opportunities for socially disadvantaged population groups (Beckert and Lutter, 2009). Gambling takes place primarily in the environment of gambling establishments and the community of gamblers includes people with low incomes, often unemployed and recipients of social benefits. Gambling deepens the impacts of adverse socioeconomic factors on the population in regions affected by socio-economic disadvantages (Abbott et al., 2013). On the other hand, in economically stronger regions, gamblers prefer the Internet or live casino games. Both of these factors have a direct impact on the spatial distribution of gambling in the territory. Wardle et al. (2014) showed in their study that in the UK, the areas with a high density

\footnotetext{
${ }^{1}$ The data for the year 2015 were not analysed due to their unavailability during the processing of this paper.
} 
of gambling equipment correlate with areas of socioeconomic deprivation (formerly economically thriving ports and older industrial cities).

As shown in some studies, for example by Hampton (2010), peripheral border regions are also economically interesting areas for gambling. The gambling landscape has a tendency to develop in this area, often because on one side of the border, gambling is strictly regulated, while on the other side the legislation is more indulgent. This legislative inequality creates economic opportunity for agents working in the gambling industry. Casinos in the border areas primarily work because of the demand from abroad and have only a probable effect on the local population (Felsenstein and Freeman, 2002). Local casinos increase revenues from tourism and are a source of so-called gambling tourism (Zagoršek and Jaklic, 2009). On the other hand, the peripheral regions that are not determined primarily by location, but rather by the social and economic characteristics of the population, are associated with gambling to a much lesser extent. The same can be said for regions with strong entrenched traditionalism and religiosity (Diaz, 2000).

\section{Geographical context of the study}

In the Czech Republic, with its experience of many years of gambling, research on gambling is carried out, but it is not as well established as in Western European countries. In terms of the subject, local research, which is implemented mostly within the medical sciences, focuses primarily on the socio-pathological and medical manifestations of gambling in society, the availability and functioning of addiction services, and possibilities of prevention and treatment of gambling addiction (Mravčík, 2015). Some attention has been devoted also to a comparison of conditions for the operation of gambling in the environment of the European Union, and for the issues of the operation and taxation of gambling in the Czech Republic (Vlčková, 2011).

In the scope of Czech geographical research, the topic of gambling became a part of its subject orientation only a short time ago, and only in a marginal way. An overview of gambling and associated problems in the Czech Republic, including a summary of the historical context, legislation, prevalence and research base and agenda, was recently presented by Szczyrba et al. (2015). A popular learned article by Perlín and Bednářová (2015) discussed the negative consequences of gambling for Czech society. The issues of accessibility and the regulation of gambling in the city of Olomouc and its suburban hinterland have been analysed by Fiedor et al. (2016).

Globally, gambling is most often associated with large cities, and only exceptionally with rural areas. The Czech Republic (Fig. 1) is a country with 10.5 million inhabitants, with the level of urbanisation of about $70 \%$. The largest cities are Prague $(1,200,000)$, Brno $(380,000)$, Ostrava $(300,000)$ and Plzeň $(160,000)$. The settlement structure in the Czech Republic is characterised by a higher proportion of small towns (under 10,000 inhabitants) and six thousand small rural municipalities (Majerová, 2007). It is important to note that casino games or EGMs were operated in 1,926 municipalities in the Czech Republic in 2010, while in 2014 it was only in 1,560 municipalities. Considering this fact and the formulation of the research questions in the introduction, we evaluated the basic geographic aspects of gambling at the level of higher administrative units, i.e. the administrative districts of municipalities with extended powers (total 205) and the City of Prague. Exceptionally, we assessed the geographic aspects of gambling at the level of individual municipalities (6,250 municipalities in 2010; 6,253 municipalities in 2014).

\section{Data and methods}

The Czech Ministry of Finance has a privileged position in the area of data collection on gambling operations in the Czech Republic, as well as their monitoring and control. With regard to the research questions raised in the introduction, we can divide the data that is used into two main spheres: data on the number of EGMs operating in particular municipalities of the Czech Republic; and data on the tax revenues of municipalities from gambling. The data on the number of inhabitants in the years 2010-2014 were

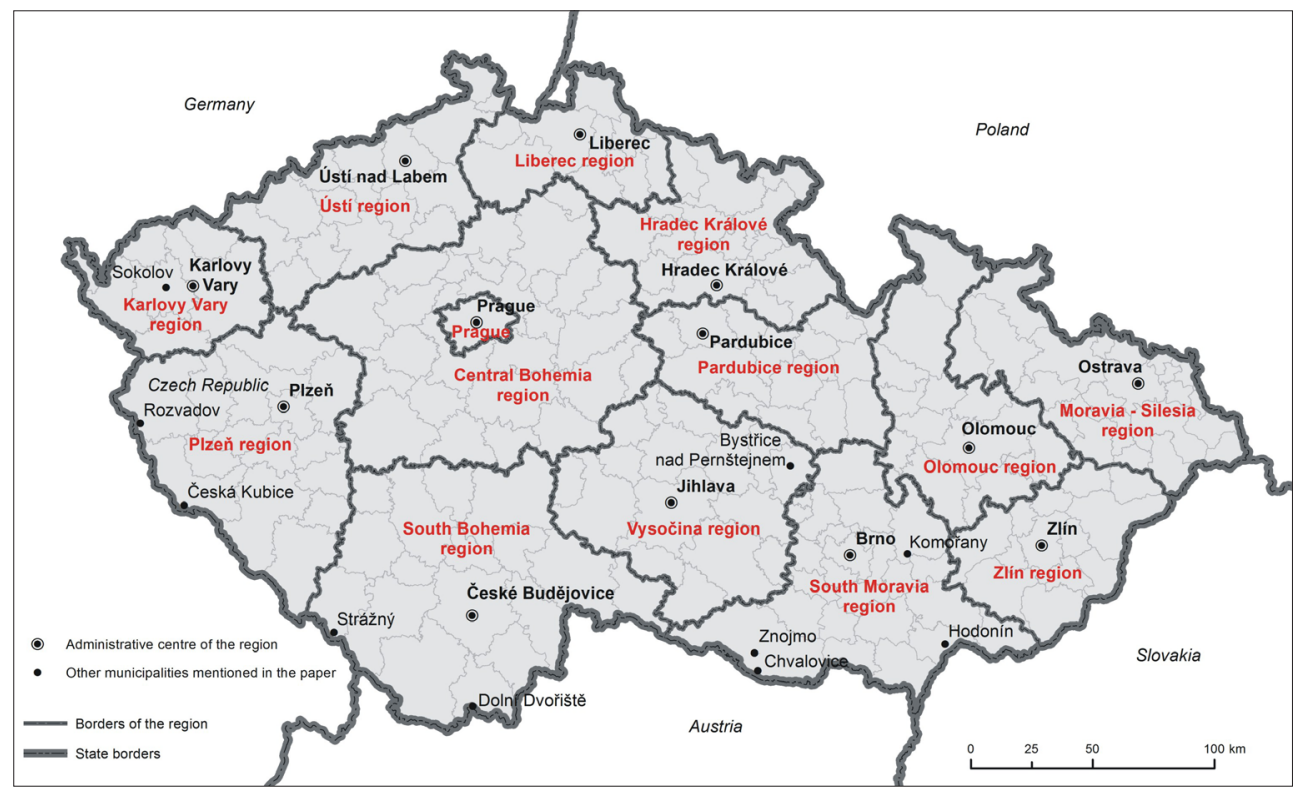

Fig. 1: The Czech Republic: an overview map. Source: authors' processing

Note: The current administrative structure of municipalities with extended powers is available at Regional Information Service: Ministry of Regional Development (2017) 
drawn from the public database of the Czech Statistical Office and, like the number of EGMs in operation, the decisive date was the end of the year ${ }^{2}$.

In 2013, the Ministry of Finance began to publish a regular informative summary of licensed EGMs and casino games (before 2013, the informative lists were provided only on request). Each line in the list of approved EGMs (or casino games) represents just one specific licensed machine/ game. From the data, we can read the entire address where the licensed game is located, the type of game (video lottery terminals [hereinafter VLTs], electro-mechanical roulette, slot machines, casino games, etc.), their operators, and even the series number of each licensed game. On the other hand, the published informative lists of licensed EGMs and casino games have their limits. Probably the most prominent pitfall in using these data is the fact that the lists only include games that were licensed by the Ministry of Finance (slot machines accepting domestic currency outside casinos are licensed by the municipalities themselves). To obtain this important component of the data, we contacted the Ministry of Finance with a request based on an application of Act No. 106/1999 Coll., on free access to information ${ }^{3}$.

This is the only possible way to get a complete overview of all the licensed EGMs and casino games. Nevertheless, since 2012, the Ministry of Finance no longer has the precise addresses at which the slot machines licensed by municipalities are operated, which partially obstructs research conducted at the local level. Another equally significant limitation on the use of the data is the fact that the information on the addresses of licensed games is sometimes incorrect (non-existent combination of a street name and house number, misprints of names, etc.). Besides the lists of licensed EGMs and casino games, the Ministry of Finance also issues lists of currently applicable municipal ordinances that regulate (or ban) gambling. Because of the general legislation, every municipality has an obligation to notify the Ministry of Finance, which then initiates administrative proceedings to remove licences to operate machines/games that are in conflict with a newlyadopted municipal ordinance. The list is updated and available on the website of the Ministry of Finance of the Czech Republic.

Data regarding budgets and accounting information for all levels of the state administration and local government is collected by the MONITOR information portal of the Ministry of Finance. In the analytical section of this portal, it is possible to export the required items of tax revenue of each municipality as an MS Excel spreadsheet. The items searched for our purposes are under numbers 1347 and 1351 (in 2010) or 1351 and 1355 (in 2014) in the lists of municipalities' revenues classified according to the type of revenue. The sum of these items results in the total income of municipalities from gambling ${ }^{4}$, which is analysed here.
The total tax revenues of municipalities were exported from the analytical part of the MONITOR portal by exporting class 1 Tax revenues according to the category of the budget structure.

Analysis of the spatial distribution of EGMs and casino games or municipal revenues from gambling is constructed on the basis of the proportion of the number of licensed EGMs and casino games per thousand inhabitants of the administrative unit (administrative district of a municipality with extended powers) or per the total amount of tax revenue. To capture any changes in the number of EGMs or casino games and changes in revenues from gambling in the period 2010-2014, we used the so-called change index (CI), i.e. the proportion of the number of EGMs and casino games (i.e. the income from gambling) in 2014 and 2010 reported as a percentage, i.e. multiplied by $100([\mathrm{CI}=100] \approx$ no change; $[\mathrm{CI}>100] \approx$ an increase; $[\mathrm{CI}<100] \approx$ a decrease in the number of EGMs and casino games in a given administrative unit). For the analysis of the proportion of gambling-based revenues in total municipal tax revenues we used a multiple box plot (Potter et al., 2006). The data showed in the chart (medians, box plot boundaries - the upper and lower quartiles, the non-outlier range values) were set to correspond with the nature of the data. For the sake of clarity, we have omitted outlier values, which are values exceeding the size of the box by 1.5 times. We are aware of losing full variability of the original data, on the other hand the outliers are extreme values which should have distorted the analysis. Specific municipalities with extreme values are mentioned in the manuscript and they are discussed below in the text. We used the STATISTICA software for drawing the boxplot.

Following the analysis of the spatial distribution of EGMs and casino games, we evaluated the change in the concentration of EGMs between 2010 and 2014 using a Lorenz curve and the Gini coefficient. In our evaluation, we used the number of EGMs including casino games and the population of each municipality. The Gini coefficient can be calculated as the ratio of the area bounded by a diagonal (the axis of the first quadrant of the Cartesian system of coordinates) and the Lorenz curve to the total area below the diagonal. In practice, however, the so-called Brown formula (Brown, 1994) is usually used:

$$
\mathrm{G}=\left|1-\sum_{i=1}^{n}\left(x_{i}-x_{i-1}\right) *\left(y_{i}+y_{i-1}\right)\right|,
$$

where $x_{i}$ and $y_{i}$ are the relative cumulative frequencies of both characteristics, $\mathrm{x}_{0}=0$ and $\mathrm{x}_{\mathrm{n}}=1$. It uses values from 0 to 1 , where the value of the Gini coefficient approaching zero indicates the most even distribution of a phenomenon in the researched space and, vice versa, a value close to 1 reveals an extremely unequal distribution.

\footnotetext{
${ }^{2}$ Our analyses include the total population of the spatial units in question. At first, we planned to relativise the data using the population aged 18 and over, but then we refrained from that because of the lower availability of data on the spatial distribution of this age category and also because of the fact that the revenues from gambling that accrue to the budgets of municipalities can theoretically benefit all age groups.

${ }^{3}$ The Czech Ministry of Finance archives all requests for information and data which were handled and thus it is possible to find on their website (www.mfcr.cz) all the data about the location of slot machines licensed by municipalities with which the authors worked (Ministry of Finance of the Czech Republic, 2015).

${ }^{4}$ The total revenues of municipalities from gambling do not include revenues from administrative fees for licences for slot machines because they cannot be set apart from all the administrative fees. In comparison with the above-mentioned items, however, the amount these fees represent is negligible.
} 


\section{Results}

First, an analysis of the spatial distribution of EGMs and casino games is presented. In the next part, we deal with the problems of revenues from gambling, both at the municipal level and in an aggregate form at the level of administrative districts of municipalities with extended powers. In both parts of the results, we also deal with the dynamics of the changes of these attributes of gambling in the Czech Republic (through a comparison of the years 2010 and 2014).

\subsection{Spatial distribution of EGMs and casino games in the Czech Republic}

The total numbers of EGMs and casino games differ significantly when we compare 2010 and 2014. While in 2010 the total number of gambling units in operation in the Czech Republic was 111,213, in 2014 it was only 69,713 (Ministry of Finance of the Czech Republic, 2015, 2016a). This drop was significantly influenced by the Amendment to the Lottery Act No. 300/2011 Coll., which came into force on $1^{\text {st }}$ January 2012 and granted municipalities the right to regulate gambling on their territory and also significantly increased taxation on gambling operators. In the two years in question, the major share of the gambling market (not only in the Czech Republic, but also in all administrative districts) was occupied by VLTs, which were licensed by the Ministry of Finance. Until 2012 the municipalities could not regulate their numbers (Szczyrba et al., 2015).

In 2010, slot machines licensed by municipalities constituted over $30 \%$ of all the EGMs in the country, but in 2014, this proportion was less than $18 \%$. This is connected with the fact that in a majority of the administrative districts of municipalities with extended powers, there are more machines licensed by the Ministry of Finance. In 2010, however, there were 44 administrative districts in which there were more machines licensed by municipalities than by the Ministry of Finance (Fig. 2).

These districts were administrative districts with a smaller total number of EGMs and casino games in operation that were typically demographically smaller (e.g. Konice, Nepomuk or Pacov), or administrative districts located in the Central Bohemia region (Benešov, Brandýs nad Labem-Stará

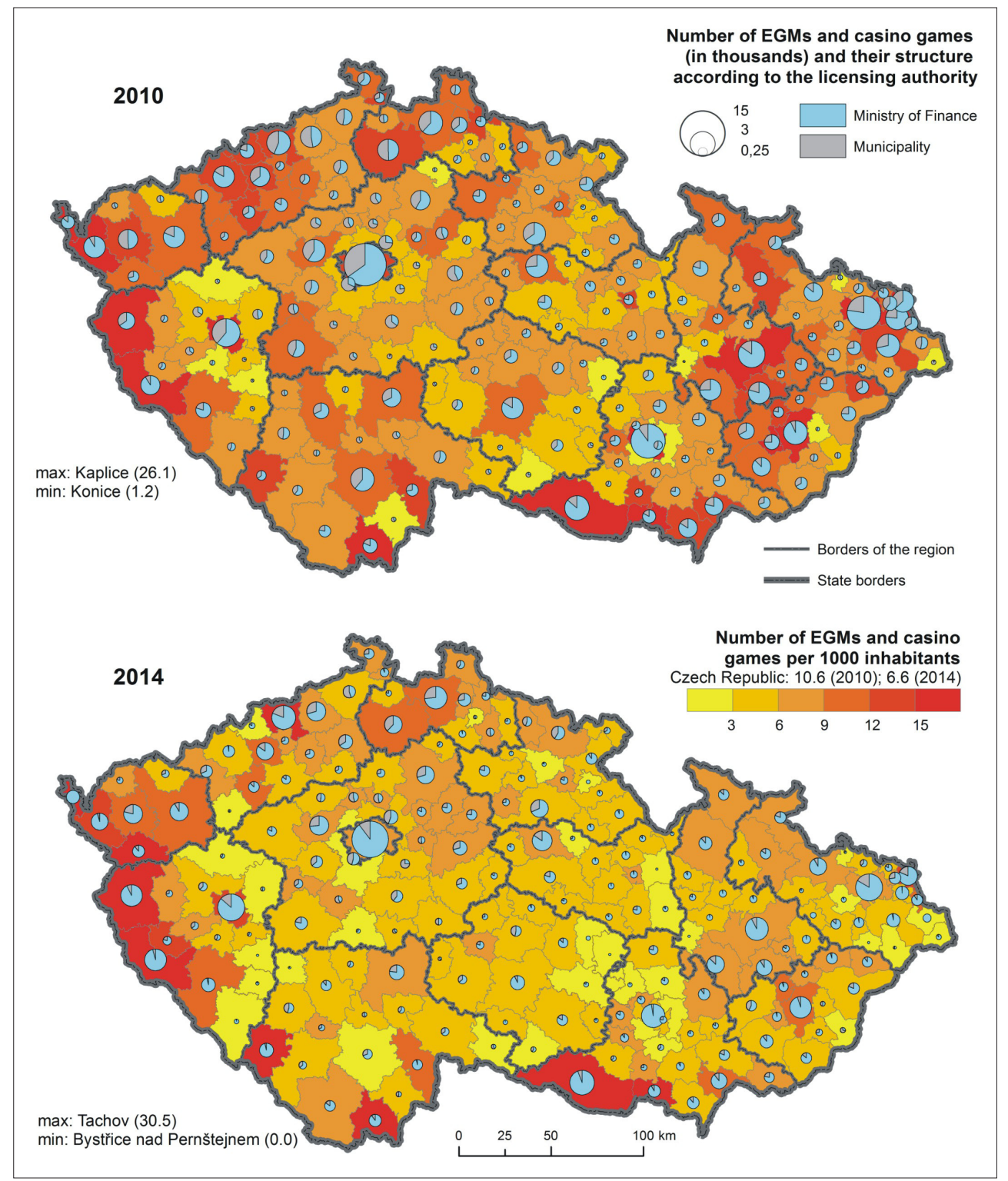

Fig. 2: Spatial differentiation of EGMs and casino games according to the administrative districts of municipalities with extended powers in 2010 and 2014 (as of $31^{\text {st }}$ December).

Sources: Czech Statistical Office (2015); Ministry of Finance of the Czech Republic (2015, 2016a); authors' processing 
Boleslav, Černošice, Kolín). On the other hand, in 2014 the number of administrative districts where the number of slot machines licensed by municipalities dominated decreased to a total of 13 . In some administrative districts, the number of slot machines licensed by the municipalities was lower in 2010, while in 2014 the number was higher: this was the case in the administrative districts of Děčín, Valašské Klobouky and Železný Brod. This change was accompanied by a significant decrease in the total number of licensed EGMs and casino games in these administrative districts. The low number of administrative districts in which there were more slot machines licensed by municipalities is primarily due to a simpler regulatory process. Slot machines are licensed or prohibited by municipalities themselves, while the EGMs and casino games licensed by the Ministry of Finance can only be banned by municipalities through an administrative procedure.

The absolute numbers of EGMs and casino games in operation in 2010 were clearly linked with the administrative districts with the city with highest population in the Czech Republic. In 2010, for example, the City of Prague had 16,156 EGMs and casino games in operation, while in 2014 it was 9,014, which is again the highest number among all of the spatial units that were observed (in relative terms, in 2010 it was $14.52 \%$ and in 2014 12.93\% of all the EGMs and casino games in operation in the Czech Republic). It is also necessary to pay attention to the administrative district of Olomouc, as on a long-term basis it has the largest number of licensed EGMs and casino games among cities with at least 50,000 inhabitants (Mravčík et al., 2014; Fiedor, 2016). In terms of the absolute numbers of licensed EGMs and casino games, the administrative district of Znojmo was sixth in 2010, and even fourth in 2014 (although it is in $21^{\text {st }}$ place according to its population). More than half of the total number of licensed EGMs and casino games within the administrative district of Znojmo are located in Chvalovice, a village between the towns of Znojmo and Retz (on the E59 highway, a former duty free zone) at the Czech-Austrian border. When the relative numbers of licensed EGMs and casino games (i.e. per 1,000 inhabitants) are compared, gambling is the most popular in the administrative districts on the Czech-Austrian and Czech-German borders (Fig. 2). This is due to the municipalities (e.g. Dolní Dvořiště, Česká Kubice or Rozvadov) with large casinos with hundreds of EGMs for visitors from neighbouring countries. Unfortunately, we do not have any data about visitors to casinos (here or in other locations in the Czech Republic), unlike other countries (Makarovič, Macur and Rončevič, 2011).

Even the distribution of the lowest values of the relative indicator of the number of EGMs and casino games per 1,000 inhabitants shows certain spatial patterns. Figure 2 shows clearly that the regions with the lowest share of slot machines relative to the population are located in areas on the borders of three or four administrative regions. In both the years under observation, the lowest category (less than three licensed EGMs and casino games per 1,000 inhabitants) involved three administrative districts of municipalities with extended powers, which are located in these areas, namely, Bystřice nad Pernštejnem (in the border area between the Vysočina region, South Moravia region and Pardubice region), Konice (in the border area between the Olomouc, South Moravia and Pardubice regions), and Kralovice (in the border area between the Plzeň, Karlovy Vary, Ústí and Central Bohemia regions). Outside the above- mentioned regions, the proportion of EGMs and casino games relative to the population was generally lower in administrative districts which were located near the borders of administrative regions.

Most of these regions can be identified with the so-called areas of the internal peripheries of the Czech Republic. By internal peripheries we mean those found in the research by Musil and Müller (2008). These authors used not only locational characteristics and economic indicators but also social indicators to outline the internal peripheries. The internal peripheries defined by these authors are spatially bound to the frontiers of the regional units and have socioeconomic characteristics that can be used to explain the lower share of EGMs and casino games. First, there is a very low value for the density of the population, pointing to a small population in these districts. In addition, the local population has a higher proportion of older people aged 65 years or over and, on the contrary, a lower proportional representation of younger population groups. These social conditions can influence the demand for gambling in the sense that the number of potential participants in gambling is limited. This may also be supported by the fact that a significant number of the economically active population commute to work on a weekly basis. The economically active population of the internal peripheries is also increasingly employed in the primary sector of the economy, which is characterised by lower wages, which implies lower purchasing power among the local population, which acts as a brake on the development of gambling. We cannot, of course, forget the relative location of the regions with the lowest proportion of EGMs and casino games. The regions are located away from the backbone communications, which is another cause of low values for this indicator.

In addition to internal peripheries on the boundaries of the regional units, the lowest values of the observed indicators are found in certain traditional areas of Moravia and Silesia. In Moravia, it is the region of southern Moravian Wallachia (the administrative districts of Valašské Klobouky and Vizovice), while in Silesia, it is the cultural-historical area of Hlučín region (the administrative districts of Kravaře and Hlučín) and Jablunkov region (the administrative district of Jablunkov). In these regions, religious observance is also an important factor. The above- mentioned regions are the areas with the highest degree of religious observance in the Czech Republic. The higher proportion of the faithful in their populations may be a reason for the small number of EGMs and casino games in these regions (Diaz, 2000).

Figure 3 illustrates several important findings on the spatial patterns of changes in the indicators under evaluation between 2010 and 2014. It is possible to identify regions in which the absolute values of EGMs and casino games increased within the monitoring period. These regions are in a minority and can be divided into two categories. The first is that of the regions situated on the Czech-German or Czech-Austrian borders. In these regions we have demonstrated high levels of relative indicators presented in Figure 2. These regions (the administrative districts of Domažlice, Horšovský Týn, Mariánské Lázně, Tachov, Trhové Sviny and Vimperk) already had high numbers of EGMs and casino games in 2010 and they increased further in the period in question. Second, there were the regions (the administrative districts of Jablunkov, Kraslice, Mnichovo Hradiště, Moravské Budějovice, Ostrov, Poděbrady, Přeštice and Vizovice) which had low numbers of EGMs and casino games (in absolute and relative terms) 


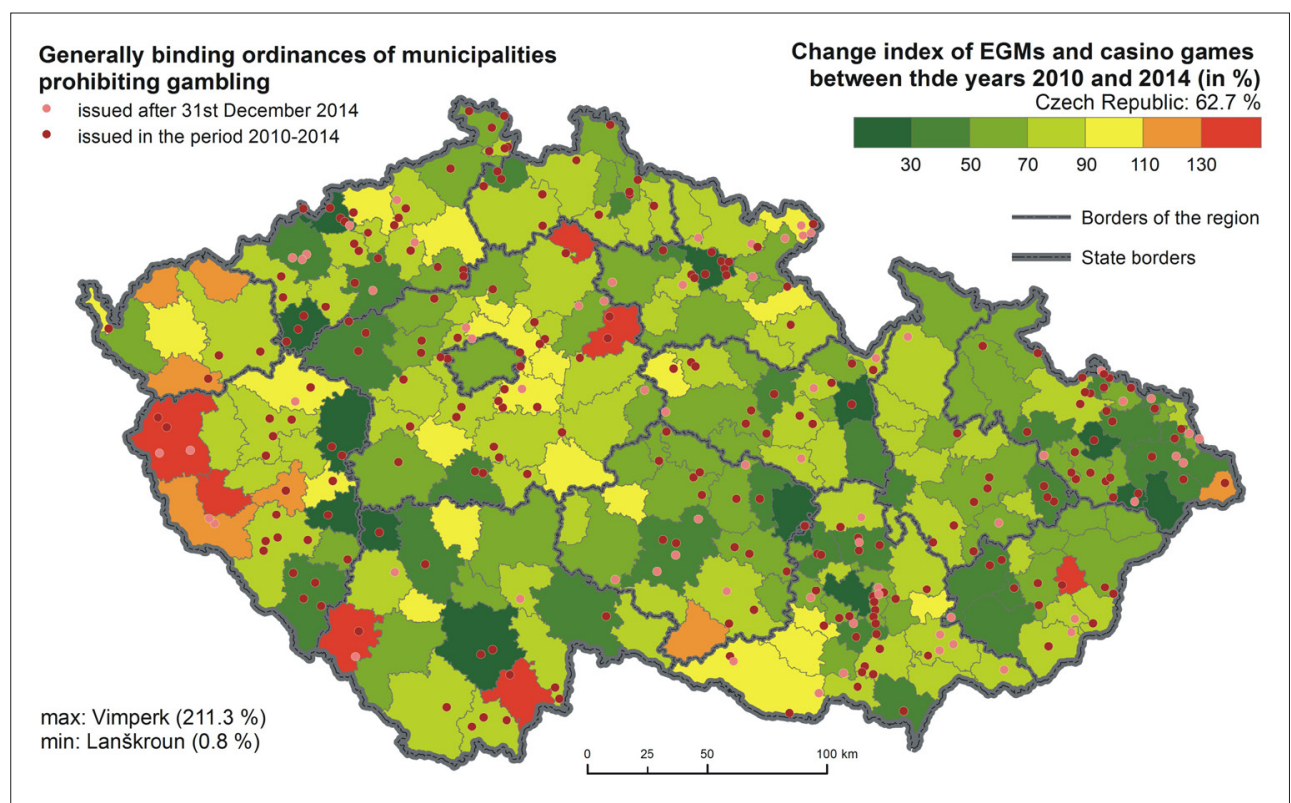

Fig. 3: Change index of the number of EGMs and casino games between 2010 and 2014 Sources: Ministry of Finance of the Czech Republic (2015, 2016a, 2016b); authors' processing

in 2010 and where, despite an increase in the numbers of the entities being monitored, their absolute numbers in 2014 were still low.

In a substantial majority of the spatial units that were observed, the numbers of the EGMs and casino games is being monitored dropped. This tendency can be attributed to the above-discussed legislative regulation of gambling which took place in 2011. The most dramatic drop in the number of EGMs and casino games occurred in the above-mentioned regions of the internal periphery. This tendency may have been affected by the above-mentioned widespread conditions dampening the proliferation of gambling, in combination with the implementation of municipal ordinances aimed at the regulation of gambling. There are many examples of such responses of municipal councils in internal peripheries: a good example is Bystřice pod Perštejnem, where the former mayor Josef Novotný contributed significantly to a ban on gambling in all public places in the municipality and later, as a senator of the Upper House of the Parliament of the Czech Republic, was the first Czech politician to pursue the strict regulation of gambling. It is also necessary to draw attention to the dramatic drop in the numbers of EGMs and casino games in core regions around cities at a high level of the administrative hierarchy, e.g. the administrative districts of Brno, České Budějovice and Jihlava. The significant drop is due to generally binding regulations aimed at the complete elimination of EGMs and casino games by the above cities in the period in question.

The Lorenz curves (Fig. 4) show the spatial concentration of EGMs and casino games in municipalities and administrative districts with extended powers in the Czech Republic. In connection with legislative changes and the overall decrease in the numbers of EGMs and casino games, we can assume that gambling began to concentrate spatially. Both graphs in Figure 4, however, show a different reality and one can see how crucial is the choice of the level of an administrative unit. At the beginning of this section, we suggested that gambling in the years in question was connected with less than a third of the municipalities. Nevertheless, the graph shows that $80 \%$ of the population live in municipalities in which gambling was or still is carried on. At the municipal level, the spatial concentration of gambling in terms of the comparison between 2010 and 2014 remained virtually unchanged (the Gini coefficient for the

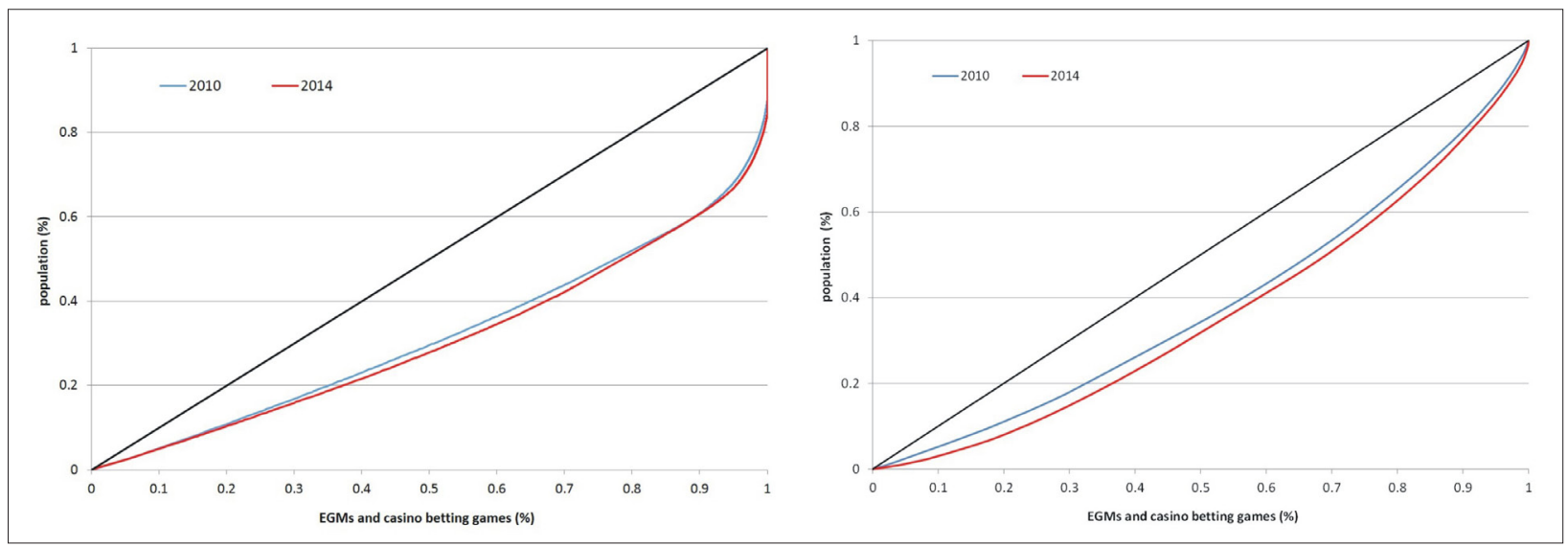

Fig. 4: Lorenz curve showing the degree of spatial concentration of EGMs and casino games in the municipalities of the Czech Republic (left) and in the administrative districts with extended powers (right) in 2010 and 2014.

Sources: Czech Statistical Office (2015); Ministry of Finance of the Czech Republic (2015, 2016a); authors' processing 
year 2010 was 0.37 and it was 0.39 in 2014). At the same time the chart on the right (Fig. 4) shows that at the level of administrative districts with extended powers all the residents had access to gambling opportunities, as there were some EGMs or casino games in each administrative district in the two years in question. Additionally, we can also observe a higher spatial concentration of gambling in 2014 (the Gini coefficient in 2010 was 0.23 and it was 0.28 in 2014). Nevertheless, the difference in the spatial concentration of gambling is not large and the small values of the Gini coefficient for the level of administrative districts can mean higher spatial refinement and the already-mentioned fact that at the level of administrative districts, everybody has access to gambling opportunities.

\subsection{Economic benefits of gambling to municipalities}

In 2010, gamblers in the Czech Republic bet CZK 125.6 billion, of which CZK 93.8 billion was paid back to gamblers as winnings (Ministry of Finance of the Czech Republic, 2016a). In comparison with 2010, in 2014 both the volume of bets (CZK 138.1 billion) and the winnings paid out (CZK 106.7 billion) increased. In all likelihood this is mainly because of the aforementioned changes to the legislation, and the municipal revenues also changed substantially. The spatial analysis of municipal revenues is the subject of the next section.

While in 2010, the municipal budgets received CZK 1.5 billion from gambling, in 2014 it was already more than CZK 5.5 billion (MONITOR, 2015). It might be useful to outline the system of levies on gambling companies, which has been fundamentally changed by the Amendment to the Lottery Act in 2011. In 2010, the income of municipalities from gambling consisted of a local fee charged for the operation of a slot machine (provided the municipality had established this fee) and a contribution for purposes beneficial to the public (social, health, sports, environmental, cultural or other welfare services), part of which the operators of EGMs had to pay directly to the municipalities. The contribution for public purposes was paid as a progressive tax amounting to $6-20 \%$ of the profit made by gambling operators. In practice, large companies were divided and subsidiaries established on purpose to allow the parent company to divide its income and reduce the percentage of profit paid for purposes beneficial to the public

At the beginning of 2012, the Amendment to the Lottery Act (No. 300/2011 Coll.) fundamentally changed the system of charges ${ }^{5}$. The administrative fees for a licence to operate EGMs or casino games were reduced and local fees, as well as the contributions to purposes beneficial to the public, were cancelled. In addition, the exception for the lottery and gambling companies consisting of an exemption from corporate income tax (19\%) was cancelled and a flat tax rate for all gambling companies (20\%) was introduced. Moreover, in the case of EGMs, the taxation basis consists of a proportional part (20\% of the difference between the money put in and that paid back) and a fixed part (55 CZK for each EGM per day). The accounting definition of the taxation also differs according to whether it is for EGMs or lotteries and other similar games. In the case of EGMs, $80 \%$ of the taxation accrues to the municipal budget (depending on the number of EGMs), while the remaining $20 \%$ goes to the state budget. On the other hand, the income from lotteries and other similar games is divided as follows: $70 \%$ to the state budget and $30 \%$ to the budgets of the municipalities according to the classification of taxation (i.e. including those municipalities where gambling is not operated).

In 2010, the highest revenues from gambling accrued to the municipalities of the administrative districts of Vyškov, Vimperk and Kaplice (Fig. 5). The administrative district of Kaplice had the highest number of EGMs and casino games (per 1,000 of the population) of all the administrative districts; the situation in the administrative districts of Vyškov and Vimperk reflects the specific nature of the taxation of gambling in the Czech Republic before 2012, when gambling companies contributed only a part of their profits to purposes that were beneficial to the public (see above). The municipality of Komořany (700 inhabitants), in the area of the administrative district of Vyškov, is the domicile of the European Data Project ${ }^{6}$, a company producing EGMs for the European market, whose subsidiary companies, operating a network of casinos called Admiral Global Betting and American Game, contributed to the municipal budget to the tune of CZK 1 million $^{7}$ in 2010 (mostly for the development of transport infrastructure). Neither EGMs nor casino games, however, were in operation in the municipality in that year. In the administrative district of Vimperk, there is a village called Strážný (400 inhabitants), which is home to several casinos. In 2010, this municipality received more than CZK 12 million from gambling taxation, which was designated mostly for investment projects (development of the sewerage system, public lighting, etc.) in the municipality (Ministry of Finance of the Czech Republic, 2016a). Through these examples we can document the importance of the presence of a gambling company in a municipality, not just until 2012, but also afterwards (see below).

The lowest incomes from gambling were observed in administrative districts located in the inner periphery of the Czech Republic and in the administrative districts of the Vysočina region, which mostly consists of small rural municipalities. In 2014, the highest income clearly accrued to the administrative districts of municipalities with extended powers located on the Czech-Austrian and Czech-German borders (Fig. 5). The map also shows the administrative districts with those of the largest cities which did not completely ban gambling by municipal ordinances at their centre. This ban mainly affected the revenues in the municipalities of Brno and České Budějovice. The lowest revenue from gambling in 2014 was accounted for in administrative districts on the borders of three regions (e.g. Bystřice nad Pernštejnem and Konice), which is caused by the small number of EGMs installed (see section 5.1).

\footnotetext{
5 The rate of the revenues was valid until the end of 2015. Since the beginning of 2016, the new taxation on gambling has established the rates of $23 \%$ (lotteries) and 28\% (EGMs). At the same time, the rate of the fixed charge for every licensed EGM has increased to 80 CZK per day.

${ }^{6} \mathrm{EDP}$ was founded in 1996 and in terms of the number of employees (more than one thousand) it is one of the largest industrial companies in the South Moravian region. Its subsidiaries rank among the market leaders on the gambling market in the Czech Republic.

${ }^{7}$ It was an exceptional year, because in 2009 it was CZK 28 million and in 2011 CZK 10 million (Ministry of Finance of the Czech Republic, 2016a).
} 


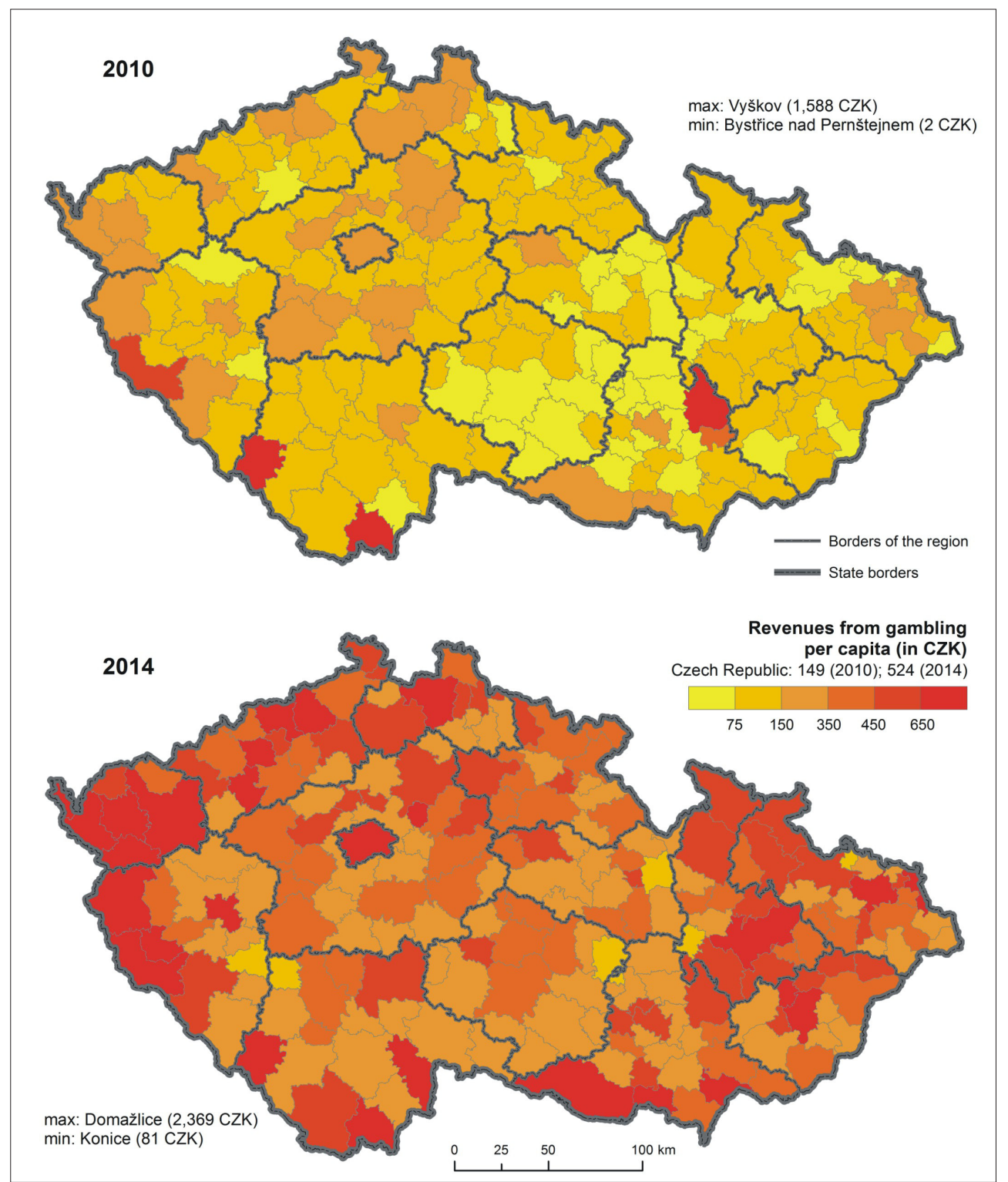

Fig. 5: Spatial differentiation of revenues from gambling according to the administrative districts of municipalities with extended powers in 2010 and 2014

Sources: Czech Statistical Office (2015); MONITOR (2015); authors' processing

The change in the absolute incomes of municipalities that constitute the administrative districts of municipalities with extended powers between 2010 and 2014 is shown in Figure 6. It is clear that only three administrative districts behave atypically (as a result of changes in the legislation and the generally expected increase in the revenues of municipalities): Bučovice, Vyškov and Vimperk. In the case of Bučovice and Vyškov, the drop in revenues from gambling is connected with a smaller number of EGMs and casino games in operation. On the contrary, the administrative district of Vimperk saw a significant increase in the numbers of EGMs and casino games in the period 2010-2014, but there was a drop in the revenue from gambling anyway. The volume of revenues that the municipality of Strážný received from the company INGO (a casino operator) in 2010 significantly exceeds the amount received in 2014 (Ministry of Finance of the Czech Republic, 2016a).

With the exception of the three administrative districts of municipalities discussed in the previous paragraph, in all the other spatial units that were observed the revenues from gambling increased. Therefore, this is an all-over phenomenon: the growth rate of revenue from gambling is uniformly present throughout the Czech Republic. It is appropriate to attribute this phenomenon just to the legislative changes in 2011. The significance of the legislative changes is emphasised by the fact that in most administrative districts, the increase in revenues from gambling was accompanied by a decrease in the number of EGMs and casino games in operation. An intensive revenue growth is present even in the administrative districts with an intensive decline in the numbers of EGMs and casino games. Only in the exceptional cases of some administrative districts can the increased revenue from gambling be seen as the current increase in the number of EGMs and casino games in operation in these regions.

The connection of gambling with the urban environment has been mentioned several times. Therefore, it is now necessary to examine the dependence of revenues from gambling on the size of a municipality. As every municipality already had at least some income from gambling in 2014, the analysis included all the municipalities of the Czech Republic. The box plot (Fig. 7) shows both the relationship 
between the incomes of municipalities from gambling and their sizes, as well as the dynamics that occurred after the aforementioned legislative changes. As already mentioned in section 3, the graph omits outliers. In 2010, the category of municipalities with up to 1,000 inhabitants showed no profits from gambling (there are nearly 5,000 municipalities with less than 1,000 inhabitants in the Czech Republic and several municipalities with low populations on the Czech-Austrian and Czech-German borders constituted outliers within this size category). On the contrary, in 2014, all the municipalities have some revenue from gambling (although in the category of municipalities with less than 1,000 inhabitants it is still a negligible amount). In 2010, the highest proportion of revenues from gambling in total tax revenues was observed in municipalities in the categories from 5,000 to 50,000 inhabitants (the differences between the categories within this range were minimal). It is possible to observe a relationship between the proportion of revenue from gambling and the size of a municipality, which is especially apparent in 2014 . We can conclude that the proportion of revenue from gambling increases together with the increasing size of the municipality. The observed

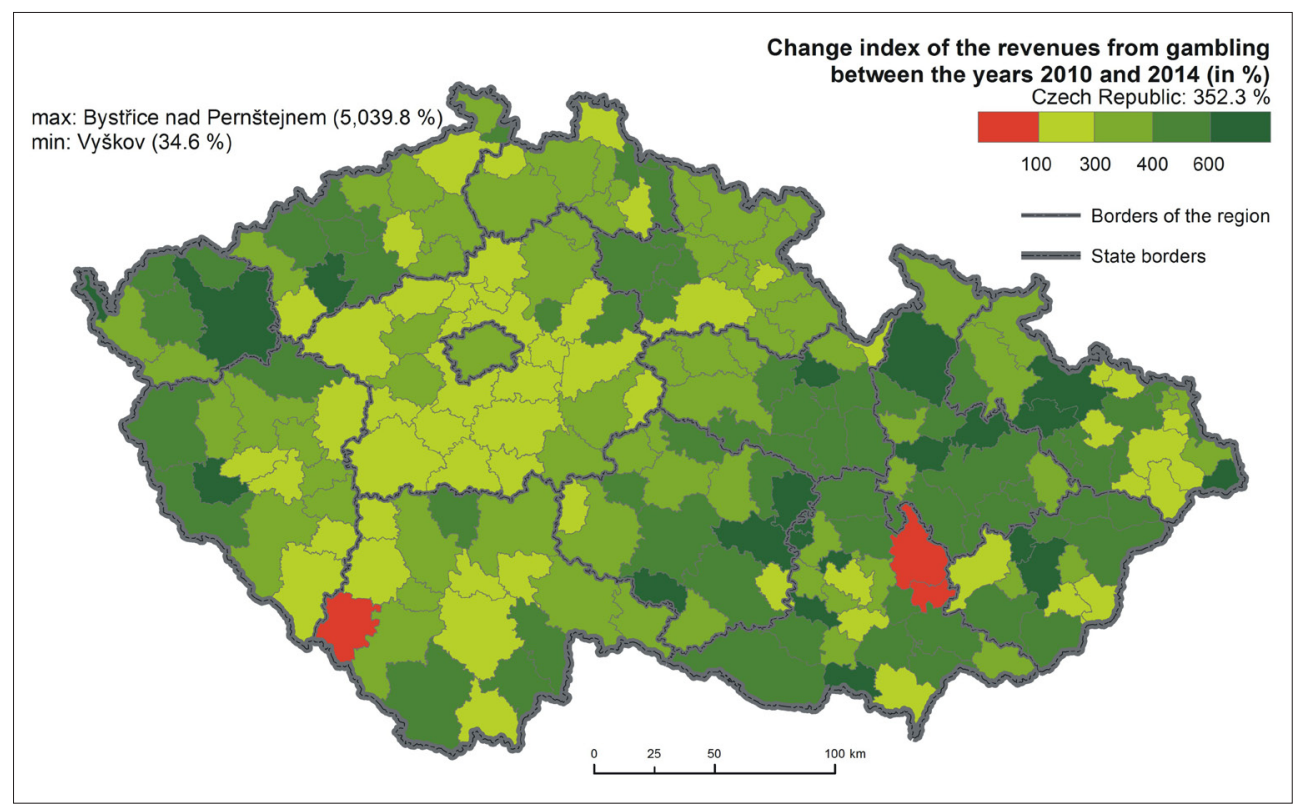

Fig. 6: Change index of gambling revenues for municipalities with extended powers in the period between 2010 and 2014. Sources: Czech Statistical Office (2015); MONITOR (2015); authors' processing

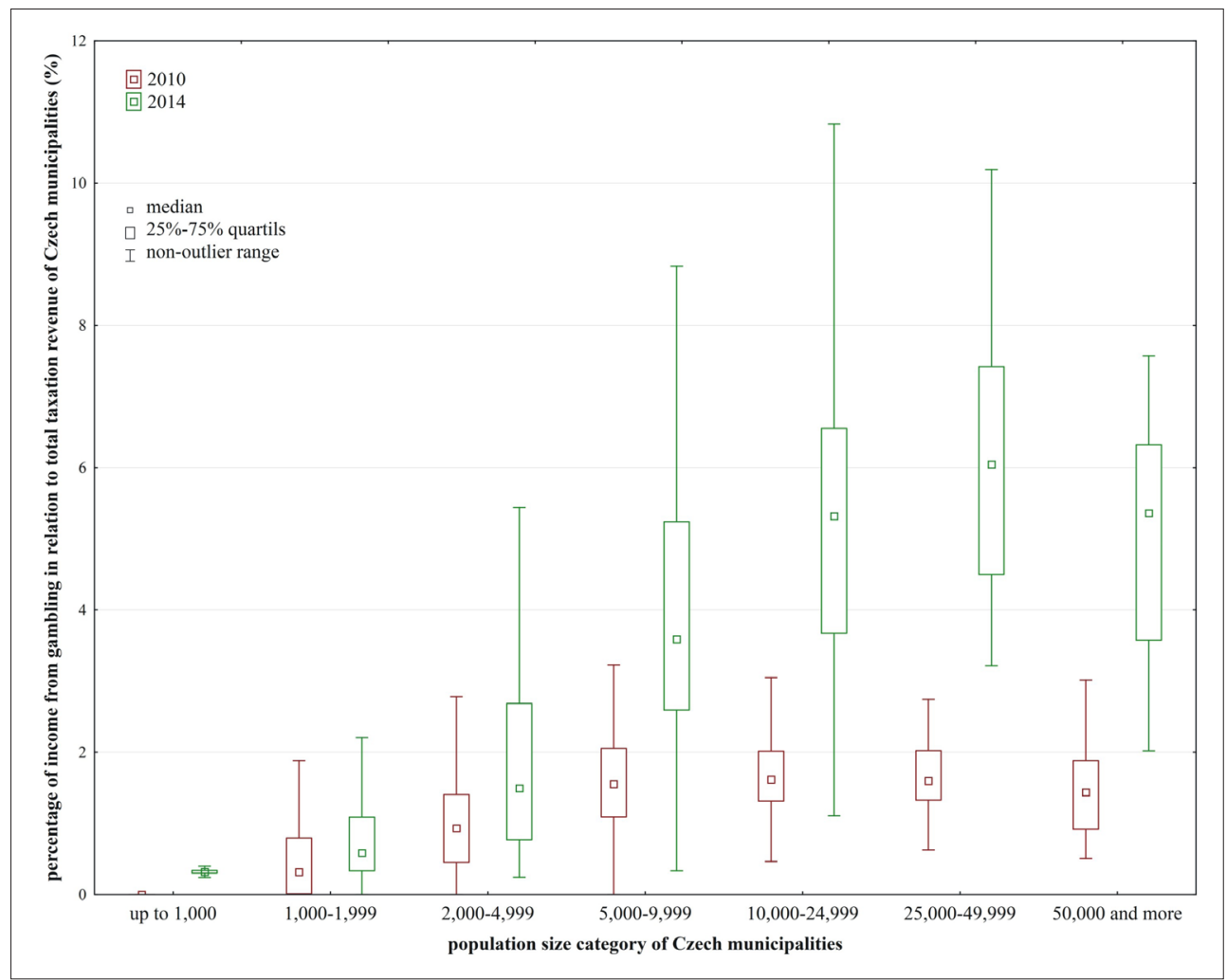

Fig. 7: Development of the proportion of revenues from gambling in the tax revenues of municipalities in 2010 and $2014\left(N_{2010}=6,250 ; N_{2014}=6,253\right)$

Sources: Czech Statistical Office (2015); MONITOR (2015); authors' processing 
phenomenon is not valid for the category of municipalities with 50,000 inhabitants or more, because these larger municipalities have considerably differentiated budgets and gambling cannot constitute a substantial part of it.

In the largest Czech cities, their current revenues from gambling typically represent about two per cent or more of all tax revenues. For example, in 2014 the City of Prague received more than CZK 0.9 billion from gambling ( $2 \%$ of the tax revenues of the city), while in 2010, the income from gambling was hardly one-third of that amount ( $0.6 \%$ of the tax revenues of the city). On the other hand, Brno, the second largest Czech city, received nearly CZK 0.2 billion to the municipal budget (i.e. 2.3\% of the total tax revenues of the city) from charges and taxes on gambling in 2014 and also, as in the case of Prague, in spite of the regulation of gambling, its revenue from gambling in 2010 was significantly lower $(0.9 \%$ of the tax revenues of the city). Among large cities (with over 50,000 inhabitants) the proportion of revenue from gambling in total tax revenues is highest in Olomouc, which collected nearly CZK 110 million in 2014, which represents more than 7\% of its tax revenues. In the categories of municipalities with between 10,000 and 50,000 inhabitants, where the revenues from gambling generally represent the largest proportion of the total tax revenues, we can mention, for example, Hodonín and Sokolov, where the revenues from gambling in 2014 accounted for more than $10 \%$ of all tax revenues. Among the small villages in the Czech Republic, the largest proportion is reached by the already-mentioned municipalities on the Czech-Austrian border (Chvalovice, where more than $90 \%$ of the tax revenue in 2014 was from gambling) or the Czech-German border (Česká Kubice, where $85 \%$ of the tax revenues in 2014 came from gambling, or Rozvadov, where the figure was almost $60 \%$ ).

\section{Discussion and conclusions}

The main objective of this paper was to assess the spatial patterns of the expansion of gambling in the Czech Republic, primarily by examining two of its attributes: EGMs and casino games, and the taxes on gambling companies that flow into municipal budgets.

In response to the research questions that were formulated, we can state that the binary dichotomy 'centre vs. periphery' applies in the context of the spatial distribution of EGMs and casino games. A majority of the regions characterised by the lowest values of the concentration of EGMs could be identified with the areas of the so-called internal peripheries of the Czech Republic delimited by Musil and Müller (2008), while a majority of the regions with higher concentrations of EGMs and casino games consisted of municipalities with extended powers with some populous towns at their centre. A certain exception in this respect is the Czech-Austrian and Czech-German border area, which is characterised by a high concentration of casinos, which can be associated with the more stringent regulation of gambling in Austria and Germany (Mravčík et al., 2014).

Similar spatial patterns can also be found in the case of the economic benefits of gambling for municipal budgets. In 2010, the old system of taxation of gambling companies enabled the return of taxes directly to municipalities, which resulted in a budget surplus in some municipalities in the administrative districts of Vimperk and Vyškov, as confirmed by the research study of Osman and Šerý (2013). Considering the economic effects on the municipal budgets, we found that the relationship of the size of the population of a municipality and the proportion of the revenue from gambling in the total tax revenues of the municipality is very important (with the exception of the larger cities in the Czech Republic). Even in the case of the largest cities, the revenues from gambling represent a substantial part of the total tax revenues of the municipality, but because of the significantly differentiated sources of income of large cities, this income is not so crucial.

For the last research question, which was devoted to an evaluation of changes in the attributes of gambling in the comparison of the years 2010 and 2014, we can also give a clear answer. An expected trend that the regulation of gambling and resulting lower number of EGMs and casino games would lead to their growing spatial concentration (Jensen, 2017), has not been confirmed (see Fig. 4).

The results of this paper largely correspond to contemporary knowledge of scientific disciplines dealing with gambling. In recent years, changing legislation has had a visible impact on the extent and regulation of gambling in the Czech Republic. The literature often mentions the regular rotation of periods of liberalisation and regulation of gambling (Marshall, 2002; Sauer, 2000), with the liberal approach of legislation to gambling bringing its development and simultaneously higher tax revenues for the state. Even in the Czech Republic, it was confirmed that gambling is closely related to the urban environment (Mravčík et al., 2014). Gambling is found in peripheral regions to a noticeably lesser extent, although casinos and gaming clubs are also often found in border areas and suburbia (Abbott and Cramer, 1993; Felsenstein and Freeman, 2002), which is also the case in the Czech borderlands. Similarly to other countries, we can see some relation between a lower degree of concentration of EGMs and casino games in regions and a higher proportion of religious believers (Diaz, 2000).

These results, based on the analysis of the spatial distribution of gambling, must be subject to critical evaluation and possiblelimitations. First, theauthors worked with data on legally authorised gambling establishments and betting games in casinos. This restriction cannot be disregarded, however, because information on illegally operated gambling cannot be obtained for the Czech Republic. Especially in cities that promote zero tolerance of hard gambling, illegally operated gambling venues may exist, but their number is not likely to be too large, as evidenced by Rossow and Bang Hansen (2015) in Norway. Neither are the official data on legally operating gambling entirely correct (incorrect or incomplete addresses of places where gambling devices and betting games in casinos are licensed), which was pointed out by Fiedor (2016) using the example of the city of Olomouc. It is, however, necessary to emphasise that when data are aggregated to higher-level territorial units, these errors do not manifest themselves. For our comparison of the periods before the major amendment to the Act on Lotteries No. 300/2011 Coll. and the period after the amendment, we used the years 2010 and 2014. Using data for individual years can be problematic, however, because in those years some more significant fluctuations in the revenues of municipalities can occur (until 2012, the operators of gambling establishments could return a part of their proceeds to anybody, including municipalities, for good public purposes). Nevertheless, the extreme cases of municipalities and administrative districts of municipalities with extended powers discussed in this paper also had similar positions on the gambling market in the Czech Republic in the following years. 
By analysing the spatial distribution of EGMs and casino games we identified regions that are characterised by a very high concentration of EGMs and casino games, which can be considered as objects for further research. Specifically, these are the municipalities situated near the Czech-Austrian and Czech-German borders, where the concentration of gambling is also associated with higher tax revenues obtained from gambling. Another direction is local-level research of gambling in cities with large populations, which are the most affected by gambling. These results could be compared with the social status, crime rates and other selected social pathological phenomena of the population of these areas. The last but definitely not the least direction for further research would be to focus on the different gambling politics of the cities and to study the potential effect of regulations of gambling on the suburban areas and hinterlands of large cities.

\section{Acknowledgement}

The paper was supported by the project of the specific research MUNI/A/1419/2016: "Integrated research of environmental changes in the landscape sphere II" and by the Palacky University Internal Grant Agency (IGA_ PrF_2016_026): "Landscape and people: Geographic analysis of environmental changes".

\section{References:}

ABBOTT, D. A., CRAMER, S. L. (1993): Gambling Attitudes and Participation: A Midwestern Survey. Journal of Gambling Studies, 9(3): 247-263.

ABBOTT, M., BINDE, P., HODGINS, D., KORN, D., PEREIRA, A., VOLBERG, R., WILLIAMS, R. (2013): Conceptual Framework of Harmful Gambling: An International Collaboration. Guelph, Ontario: Ontario Problem Gambling Research Centre (OPGRC).

BECKERT, J., LUTTER, M. (2009): The inequality of fair play: Lottery gambling and social stratification in Germany. European Sociological Review, 25: 475-488.

BINDE, P. (2013): Why people gamble: A model with five motivational dimensions. International Gambling Studies, 13: 81-97.

BROWN, M. C. (1994): Using gini-style indices to evaluate the spatial patterns of health practitioners: Theoretical considerations and an application based on Alberta data. Social Science and Medicine, 38(9): 1243-1256.

Czech Statistical Office (2015): Veřejná databáze Českého statistického úrradu [online]. [cit. 15.01.2016]. Available at: $\quad$ https://vdb.czso.cz/vdbvo2/faces/cs/index.jsf?page $=$ statistiky

DIAZ, J. D. (2000): Religion and gambling in sin-city: A statistical analysis of the relationship between religion and gambling patterns in Las Vegas residents. The Social Science Journal, 37(3): 453-458.

DORAN, B., YOUNG, M. (2010): Predicting the spatial distribution of gambling vulnerability: An application of gravity modeling using ABS Mesh Blocks. Applied Geography, 30: 141-152.

FELSENSTEIN, D., FREEMAN, D. (2002): Gambling on the Border: Casinos, Tourism Development and the Prisoners' Dilemma. In Krakover, S., Gradus., Y. [eds.]: Tourism in Frontier Areas. Oxford, Lexington Books.
FIEDOR, D. (2016): Gambling and its Accessibility: Case Study of Olomouc (Czech Republic). Acta Universitatis Palackianae Olomucensis - Geographica, 47(1): 5-20.

FIEDOR, D., SZCZYRBA, Z., SMOLOVÁ, I., ŠURÁŇ, Z. (2016): Hazard v Olomouci a jejím zázemí: diskuse k rizikům ovlivňujících kvalitu života urbánní a suburbánní populace. In: Ira, V. [ed.]: Městská a příměstská kvalita života $\mathrm{z}$ geografického hlediska (příklad městského regionu Olomouc). Olomouc: Univerzita Palackého v Olomouci.

FIJNAUT, C., LITTLER, A. (2007): The Regulation of Gambling: European and National Perspectives. Leiden, Brill.

GRIFFITHS, M. (1999): Gambling technologies: Prospects for problem gambling. Journal of gambling studies, 15: $265-283$.

HAMPTON, M. P. (2010): Enclaves and ethnic ties: The local impacts of Singaporean cross-border tourism in Malaysia and Indonesia. Singapore Journal of Tropical Geography, 31(1): 239-253.

JENSEN, C. (2017): Money over misery: restrictive gambling legislation in an era of liberalization. Journal of European Public Policy, 24(1): 119-134.

KLEBANOW, A. M., GALLAWAY, S. M. (2015): Casinos and the City. A White Paper on the History of Casino Development in Cities, Past and Current Trends, and Recommendations for Future Development. Las Vegas, NV: Global Market Advisors.

KRIŽAN, F., BILKOVÁ, K., KITA, P., HORŇÁK, M. (2015): Potential food deserts and food oases in a post-communist city: Access, quality, variability and price of food in Bratislava-Petržalka. Applied Geography, 62: 8-18.

MAJEROVÁ, V. (2007): Social Factors Influencing the Differences between Developed and Less Developed Regions. Agricultural Economics, 53(11): 513-517.

MAKAROVIČ, M., MACUR, M., RONČEVIČ, B. (2011): Policy Challenges of Problem Gambling in Slovenia. Ljetopis socijalnog rada, 18(1): 127-152.

MARKHAM, F., DORAN, B., YOUNG, M. (2014): Estimating gambling venue catchments for impact assessment using a calibrated gravity model. International Journal of Geographical Information Science, 28(2): 326-342.

MARSHALL, D. C. (2002): A geography of gambling: electronic gaming machines in Richmond-Tweed. Ph.D. thesis, University of New England, Armidale, Australia.

MARSHALL, D. (2005): The Gambling Environment and Gambler Behaviour: Evidence from Richmond-Tweed, Australia. International Gambling Studies, 5(1): 63-83.

McCARTHY, J. (2002): Entertainment-led regeneration: the case of Detroit. Cities, 19(2): 105-111.

McMILLEN, J. [ed.] (1996): Gambling cultures: studies in history and interpretation. London; New York, Routledge.

Ministry of Finance of the Czech Republic (2015): Žádost o poskytnutí informací ve smyslu zákona č. 106/1999 Sb. [online]. [cit. 26.01.2016]. Available at: http://www. $\mathrm{mfcr.cz} / \mathrm{cs} / \mathrm{o}$-ministerstvu/sluzby-verejnosti/informacnikancelar/seznam-podanych-zadosti/2015/zadost-oposkytnuti-informaci-ve-smyslu-22647 
Ministry of Finance of the Czech Republic (2016a): Loterie a sázkové hry [online]. [cit. 26.01.2016]. Available at: http://www.mfcr.cz/cs/soukromy-sektor/loterie-asazkove-hry

Ministry of Finance of the Czech Republic (2016b): Obecně závazné vyhlášky obcí České republiky [online]. [cit. 26.01.2016]. Available at: http://www.mfcr.cz/assets/ cs/media/Prehled_2015-11-25_Obecne-zavaznevyhlasky-obci.pdf

Ministry of Regional Development of the Czech Republic (2017): Regional Information Service website [cit. 03.03.2017]. Available at: http://mapy.crr.cz/tms/crr_a/ admin/index.php\#c=3536025\%252C5519376\&z $=1 \& \mathrm{l}=$ ajax admin,ajax_admin_orp,ajax_admin_zabaged\&p=\&

MONITOR (2015): Informační portál Ministerstva financí [online]. Ministry of Finance of the Czech Republic information portal [cit. 26.01.2016]. Available at: http:// monitor.statnipokladna.cz/2015/

MOORE, S. M., THOMAS, A. C., KYRIOS, M., BATES, G., MEREDYTH, D. (2011): Gambling Accessibility: A Scale to Measure Gambler Preferences. Journal of Gambling Studies, 27: 129-143.

MRAVČÍK, V., ČERNÝ, J., LEŠTINOVÁ,Z., CHOMYNOVÁ, P. GROHMANNOVÁ, K., LICEHAMMEROVÁ, Š., ZIEGLER, A., KOCAREVOVÁ, V. (2014): Hazardní hraní v České republice a jeho dopady. Praha: Úřad vlády České republiky.

MRAVČÍK, V. [ed.] (2015): Gambling in the Czech Republic in 2014 - Annual Report. Office of the Government of the Czech Republic. Praha: National Monitoring Centre for Drugs and Addiction (National Focal Point) [online]. [cit. 26.01.2016]. Available at: https://www.drogy-info.cz/ data/obj_files/25022/708/Z6_En_web_final.pdf

MUSIL, J., MÜLLER, J. (2008): Inner Peripheries of the Czech Republic as a Form of Social Exclusion. In: Musil, J. [ed.]: Space and Historical time as dimensions of Social change (pp. 75-92). Prague, Matfyzpress.

ORFORD, J., WARDLE, H., GRIFFITHS, M., SPROSTON, K., ERENS, B. (2010): The role of social factors in gambling: Evidence from the 2007 British Gambling Prevalence Survey. Community, Work \& Family, 13: 257-271.

OSMAN, R., ŠERÝ, O. (2013): Český Springfield: velká firma na malém městě. In: Osman, R. [ed.]: Geografický výzkum: participace a angažovanost (pp. 120-139). Brno, Masarykova univerzita.

PEARCE, J., MASON, K., HISCOCK, R., DAY, P. (2008): A national study of neighbourhood access to gambling opportunities and individual gambling behaviour. Journal of Epidemiology and Community Health, 62: 862-868.

PERLÍN, R., BEDNÁŘOVÁ, H. (2015): Hazardní Česko. Geografické rozhledy, 24(5): 5-7.

POTTER, K., HAGEN, H., KERREN, A., DANNENMANN, P. (2006): Methods for Presenting Statistical Information: The Box Plot. Visualization of Large and Unstructured Data Sets, 4: 97-106.

RAENTO, P., SCHWARTZ, D. G. [eds.] (2011): Gambling, Space, and Time: Shifting Boundaries and Cultures. Las Vegas: University of Nevada Press.

RAENTO, P. [ed.] (2014): Gambling in Finland. Helsinki, Gaudeamus.
RAYLU, N., OEI, T. P. (2004): Role of culture in gambling and problem gambling. Clinical psychology review, 23(8): 1087-1114.

ROBITAILLE, E., HERJEAN, P. (2008): An analysis of the accessibility of video lottery terminals: the case of Montreal. International Journal of Health Geographics, 7(2): 1-15.

ROSSOW, I., HANSEN, M. B. (2015): Gambling and gambling policy in Norway - an exceptional case. Addiction, 111(4): 593-598.

SAUER, R. D. (2000): The Political Economy of Gambling Regulation [online]. Clemson University [cit. 20.01.2016]. Available at: http://www.jogoremoto.pt/docs/ extra/9vV7hq.pdf

SHAFFER, H. J., HALL, M. N. (2001): Updating and refining prevalence estimates of disordered gambling behaviour in the United States and Canada. Canadian Journal of Public Health, 92(3): 168-172.

SZCZYRBA, Z., MRAVČÍK, V., FIEDOR, D., ČERNÝ, J., SMOLOVÁ, I. (2015): Gambling in the Czech Republic. Addiction, 110(7): 1076-1081.

THOMAS, A. C., BATES, G., MOORE, S., KYRIOS, M., MEREDYTH, D., JESSOP, G. (2011): Gambling and the Multidimensionality of Accessibility: More Than Just Proximity to Venues. International Journal of Mental Health and Addiction, 9: 88-101.

VLČKOVÁ, M. (2011): Evaluation of revenues and fees gambling in the South Bohemian region. Acta Universitatis Bohemiae Meridionales - The Scientific Journal for Economics, Management and Trade, 14(1): 153-160.

WARDLE, H., KEILY, R., ASTBURY, G., REITH, G. (2014): "Risky Places?": Mapping Gambling Machine Density and Socio-Economic Deprivation. Journal of Gambling Studies, 30(1): 201-212.

WELTE, J.W., BARNES, G. M., TIDWELL, M. C., HOFFMAN, J. H. (2009): Legal gambling availability and problem gambling among adolescents and young adults. International Gambling Studies, 9: 89-99.

WELTE, J. W., WIECZOREK, W. F., BARNES, G. M., TIDWELL, M. C., HOFFMAN, J. H. (2004): The relationship of ecological and geographic factors to gambling behavior and pathology. Journal of Gambling Studies, 20: 405-423.

WHEELER, S. A., ROUND, D. K., WILSON, J. K. (2011): The relationship between crime and electronic gaming expenditure: Evidence from Victoria, Australia. Journal of Quantitative Criminology, 27(3): 315-338.

WILLIAMS, R. J., REHM, J., STEVENS, R. M. G. (2011): The Social and Economic Impacts of Gambling. Final Report prepared for the Canadian Consortium for Gambling Research. March 11, 2011.

YOUNG, M., LAMB, D., DORAN, B. (2009): Mountains and Molehills: a spatiotemporal analysis of poker machine expenditure in the Northern Territory of Australia. Australian Geographer, 40(3): 249-269.

YOUNG, M., MARKHAM, F., DORAN, B. (2012): Placing Bets: gambling venues and the distribution of harm. Australian Geographer, 43(4): 425-444. 
Zákon č. 300 ze dne 6. září 2011, kterým se mění zákon č. 202/1990 Sb., o loteriích a jiných podobných hrách, ve znění pozdějších předpisů, a další související zákony. In: Sbírka zákonů České republiky 2011, částka 106, 3823-3831.

ZAGORŠEK, H., JAKLIČ, M. (2009): Resort casino development and its linkage to national and international tourism: a Slovenian perspective. In: Eadington, W.,
Doyle, M. R. [eds.]: Integrated Resort Casinos: Implications for Economic Growth and Social Impacts. Reno: University of Nevada.

ZIOLKOWSKI, S. (2016): The World Count of Gaming Machines 2015. Gaming Technologies Association.

\section{Please cite this article as:}

FIEDOR, D., SZCZYRBA, Z., ŠERÝ, M., SMOLOVÁ, I., TOUŠEK, V. (2017): The spatial distribution of gambling and its economic benefits to municipalities in the Czech Republic. Moravian Geographical Reports, 25(2): 104-117. Doi: 10.1515/mgr-2017-0010. 